Bangladesh J. Bot. 44(3): 437-442, 2015 (September)

\title{
INFLUENCE OF IRRIGATION REGIMES AND WEED MANAGEMENT PRACTICES ON WATER USE AND NUTRIENT UPTAKE IN WHEAT (TRITICUM AESTIVUM L. EMEND. FIORI AND PAOL.)
}

\author{
SK Verma*, SB Singh ${ }^{1}$, SK Prasad, RN Meena and RS Meena \\ Department of Agronomy, I. Ag. Sc., BHU, Varanasi, UP, India-221 005
}

Key words: Herbicides, Water use efficiency, Nutrient content, Weed, Wheat yield

\begin{abstract}
A field experiment was conducted in sandy clay loam soil during winter season of 2012-13. The lowest weed dry weight and the highest nutrient content were recorded under $80 \mathrm{~mm}$ CPE. Significantly the highest grain and straw yield, total nutrients uptake, and the highest consumptive use of water $(57.8 \mathrm{~cm})$, rate of water use $(4.52 \mathrm{~mm} /$ day $)$, water use efficiency $(87.3 \mathrm{~kg} / \mathrm{ha}-\mathrm{cm})$ and soil profile moisture was extracted with irrigation at $40 \mathrm{~mm}$ CPE. Application of sulfosulfuron recorded significantly lowest weed biomass and the highest nutrient content and their uptake, grain and straw yield, and maximum consumptive use of water $(51.5 \mathrm{~cm})$, rate of water use $(4.02 \mathrm{~mm} /$ day $)$, water use efficiency $(91.3 \mathrm{~kg} / \mathrm{ha}-\mathrm{cm})$ and soil profile moisture extraction over metribuzin and it was at par with metsulfuron-methyl. Grain $(6.57 \mathrm{~kg} / \mathrm{ha})$ and straw yield $(12.3 \mathrm{~kg} / \mathrm{ha})$ will be reduced by an increased in unit dry matter production in weeds.
\end{abstract}

\section{Introduction}

During the post-green revolution period, the productivity of wheat (Triticum aestivum L. emend. Fiori and Paol.) has increased tremendously but is still far below the potential yield (11.2 tonnes/ha) (Singh et al. 2010). Among various factors that affect the yield of wheat, availability of water and weed management are of supreme importance (Nadeem et al. 2007). Water is a key input for all recommended agronomic practices and therefore efficient utilization of irrigation water is essential for wheat. Weeds compete with crops for water, nutrients and other growth factors, and in absence of an effective control measures, weeds remove considerable quantity of applied nutrients resulting in higher loss in yield and conditions become severe under its scarcity (Sharma and Singh 2011). The yield increases significantly with increase in the level of irrigation from three to six (Mahbod et al. 2009). Appropriate weed-control measures can improve the efficiency of use of water in wheat. Nadeem et al. (2010) reported increase in weed population and dry weight with increase in irrigation level from 0.60 to $1.00 \mathrm{IW}$ : CPE. Jain et al. (2007) found that nitrogen, phosphorus and potassium uptake by the crop was 67.07, 65.97 and $64.97 \%$, respectively less when the weed are allowed to grow throughout the crop growing season compared with the treated plots. Weed infestation during the crop period causes more than $43.63 \%$ reduction in grain yield, depending on the weed densities and type of weed flora present (Verma et al. 2008).

Necessity of adequate weed control treatments and timely water supply in crop production field through irrigation scheduling is present demand to save water and increases efficiency of water use and water productivity. Keeping above facts in mind, the present study entitled water use, nutrient content and their uptake as influenced by irrigation regimes and weed management practices in wheat was undertaken.

*Author for correspondence: <suniliari@gmail.com>. ${ }^{1}$ Department of Agronomy, KVK, Jakhdhar, Rudraprayag, GBPUA\&T, Pantnagar, Uttrakhand. 


\section{Materials and Methods}

The field experiment was conducted during winter (rabi) season of 2012-13 at Agricultural Research Farm, Institute of Agricultural Sciences, Banaras Hindu University, Varanasi (25 $18^{\prime}$ $\mathrm{N}$ latitude, $83^{\circ} 03^{\prime}-\mathrm{E}$ longitude and altitude of $129 \mathrm{~m}$ above mean sea level). The soil of experimental site is sandy clay loam, $\mathrm{pH}(7.8)$, organic carbon $(0.45 \%)$ and available N P K (240, 25 and $225 \mathrm{~kg} / \mathrm{ha}$ ). Fifteen treatment combinations of three irrigation regimes, viz. 40, 60 and 80 $\mathrm{mm}$ CPE (cumulative pan evaporation) in main plot and five weed control practices, viz. weedy check, weed free (HW at 20 and 40 DAS), sulfosulfuron, metribuzin and metsulfuron-methyl (25, 210 and $6 \mathrm{~g} / \mathrm{ha}$ ) were applied at post-emergence in sub plot. These were evaluated under split-plot design with three replications. The wheat variety 'HUW 234' was sown on 1st December 2012 with the help of ferti-seed drill at $22.5 \mathrm{~cm}$ row spacing using $100 \mathrm{~kg}$ seed $/ \mathrm{ha}$ in $4.6 \times 5.5 \mathrm{~m}^{2}$ gross plot size. As per the treatment, $6 \mathrm{~cm}$ water was applied per irrigation by fixing Parshal flume in irrigation channel. CPE was worked out from the daily Epan data taken from I. Ag. Sc., BHU observatory. Herbicides were applied with the help of flat fan nozzle attached to the foot sprayer using volume of spray 500 litters/ha, at 32 days after sowing. A basal dose of NPK (40:60:40 $\mathrm{kg} / \mathrm{ha}$ ) was applied and remaining $80 \mathrm{~kg} \mathrm{~N}$ was top-dressed in two equal splits, each at after first irrigation and flowering time. General crop management practices were followed. Data on weed was recorded from an area enclosed in the quadrate of $0.25 / \mathrm{m}^{2}$ randomly selected at three places in each plot. Oven dry weight of weeds was recorded. Grain and straw yield at harvest on both attributes were studied. Soil moisture was determined at the time of sowing, before each irrigation, two-three days after each irrigation and at harvest and expressed as personage of total profile use. From the soil moisture content and available meteorological data, computation of consumptive use of water, rate of water use, water use efficiency and moisture extraction pattern was done as described by Dastane (1972).

\section{Results and Discussion}

Dry weight of weeds significantly affected by irrigation regimes and weed management practices (Table 1). Significantly the lowest dry weight of weed was recorded with application of irrigation at $80 \mathrm{~mm} \mathrm{CPE} \mathrm{over} 60 \mathrm{~mm} \mathrm{CPE}$ and $40 \mathrm{~mm} \mathrm{CPE}$, respectively. The decrease in dry weight of weeds at lower rate of irrigation resulted from the least availability of moisture (Singh and Singh 2004), which provides inadequate growing environment to weeds (Verma et al. 2008). Application of sulfosulfuron caused significant reduction in dry weight of weeds over metribuzin and it was at par with metsulfuron-methyl. These results are corroborated with findings of Singh et al. (2009).

Irrigation at $40 \mathrm{~mm} \mathrm{CPE}$ resulted into significantly the grain and straw yield followed by irrigation at 60 and $80 \mathrm{~mm} \mathrm{CPE}$, respectively. The better development of crop under irrigated treatments was a result of better moisture availability, which maintained the internal water balance of the plant (Masanta and Malik 2009). Weed management practices, application of sulfosulfuron resulted significantly the highest grain and straw yield over metribuzin and it was at par with metsulfuron-methyl. The reason for higher values on growth parameter can be discussed in the light of fact that crop under this treatment had comparatively less weed competition. The reduction in weed competition in wheat by the use of herbicides or hand weeding not only favoured the crop growth with abundant availability of moisture, nutrients, light and space, but also reduced the overall weed interference, facilitating vigorous growth and development of crop plants and finally produce more grain and straw yield of wheat. These results are corroborated with the findings of Singh et al. (2009). 
The values of consumptive use of water, at the best, could be an under estimation in the current experiment as the ground water table would not have contributed to the water needs of the crop. So for as the irrigation regimes are concerned, irrigation at $40 \mathrm{~mm}$ CPE resulted higher

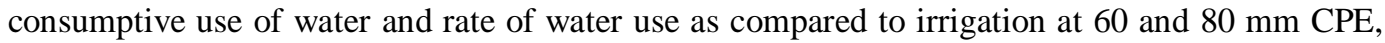
respectively (Table 2). Increase in consumptive use of water and rate of water use were mainly due to increased moisture supply by increased quantity of irrigation water. The consumptive use of water and rate of water use increased with increase in the water supply was also reported by Verma and Idnani (2012). The relative difference in the consumptive use of water and rate of water use values among different irrigation regimes was of smaller magnitude. This could be attributed to the explanation that consumptive use of water and rate of water use (soil moisture studies) were confined only $0-90 \mathrm{~cm}$ soil depth as per the depth of wheat roots and secondly, more quantity of irrigation water given by virtue of sufficient number of irrigations at $40 \mathrm{~mm}$ CPE was of additional use to the crop, whereas, irrigation at 60 and $80 \mathrm{~mm}$ CPE provided an insufficient amount of water leading to poor yield, consumptive use of water and rate of water use. The efficiency of water use was the highest with irrigation at $40 \mathrm{~mm}$ CPE and it was the lowest at $80 \mathrm{~mm}$ CPE due to the lower crop yield under this treatment. The highest efficiency of water use was due to the fact that much more applied water was used in the development of crop, resulted better development of yield attributes finally grain yield (Bandyopadhyay et al. 2010). Among weed management practices, application of sulfosulfuron recorded the highest consumptive use of water, rate of water use and water use efficiency followed by metsulfuron-methyl and metribuzin, respectively. This can be explained on the basis that lower density and dry weight of weeds under these treatments which reduces the water loss by weeds and increased water use and water use efficiency by crop ultimately, increased the consumptive use of water, rate of water use by the crop. Higher water use efficiency was obviously due to higher yield accompanied by saving of irrigation water (Singh and Singh 2004).

The main effect of irrigation and weed management practices on $\mathrm{N}, \mathrm{P}$ and $\mathrm{K}$ concentration in weeds was not significant (Table 2). The N, P and K content in weeds decreased with increasing number of irrigation and moisture availability was mainly due to dilution effect of these nutrients. The N, P and K content in weeds increased with the application of herbicides as compared to weedy check. The highest nutrient content in weeds was observed under sulfosulfuron treated plot followed by metsulfuron-methyl and metribuzin, respectively. This may be due to lower density and dry weight of weed, which reduces the partitioning of nutrients.

The $\mathrm{N}, \mathrm{P}$ and $\mathrm{K}$ depletion by weeds increased with increasing level of irrigation and significantly the highest depletion of nutrients $(\mathrm{N}, \mathrm{P}$ and $\mathrm{K})$ by weeds were recorded under irrigation at $40 \mathrm{~mm}$ CPE (Table 2). It could be attributed to the better soil moisture conditions, which helped in better utilization of nutrient by weeds, thereby resulting in highest weed dry weight and nutrient uptake (Verma et al. 2008). Weed management practices significantly influenced on the $\mathrm{N}, \mathrm{P}$ and $\mathrm{K}$ depletion by weeds. It was significantly the highest under metribuzin. The increase in the depletion of $\mathrm{N}, \mathrm{P}$ and $\mathrm{K}$ by weeds under this treatment was due to poor control of weeds resulted highest dry weight of weed, which corroborated with the findings of Singh et al. (2009) and Khokhar and Nepalia (2010).

Increased irrigation frequency increased $\mathrm{P}$ content in grain and straw and it was the highest with irrigation at $40 \mathrm{~mm} \mathrm{CPE}$, due to the dilution effect (Table 1). Whereas, $\mathrm{N}$ and $\mathrm{K}$ content in grain and straw decreased with increased irrigation frequency and it was found the highest at 80 and $60 \mathrm{~mm}$ CPE, respectively. Results are in close conformity with the findings of Verma and Idnani (2012). An application of sulfosulfuron recorded significantly the highest N, P and K content in grain and straw of wheat followed by metsulfuron-methyl and metribuzin, respectively. 


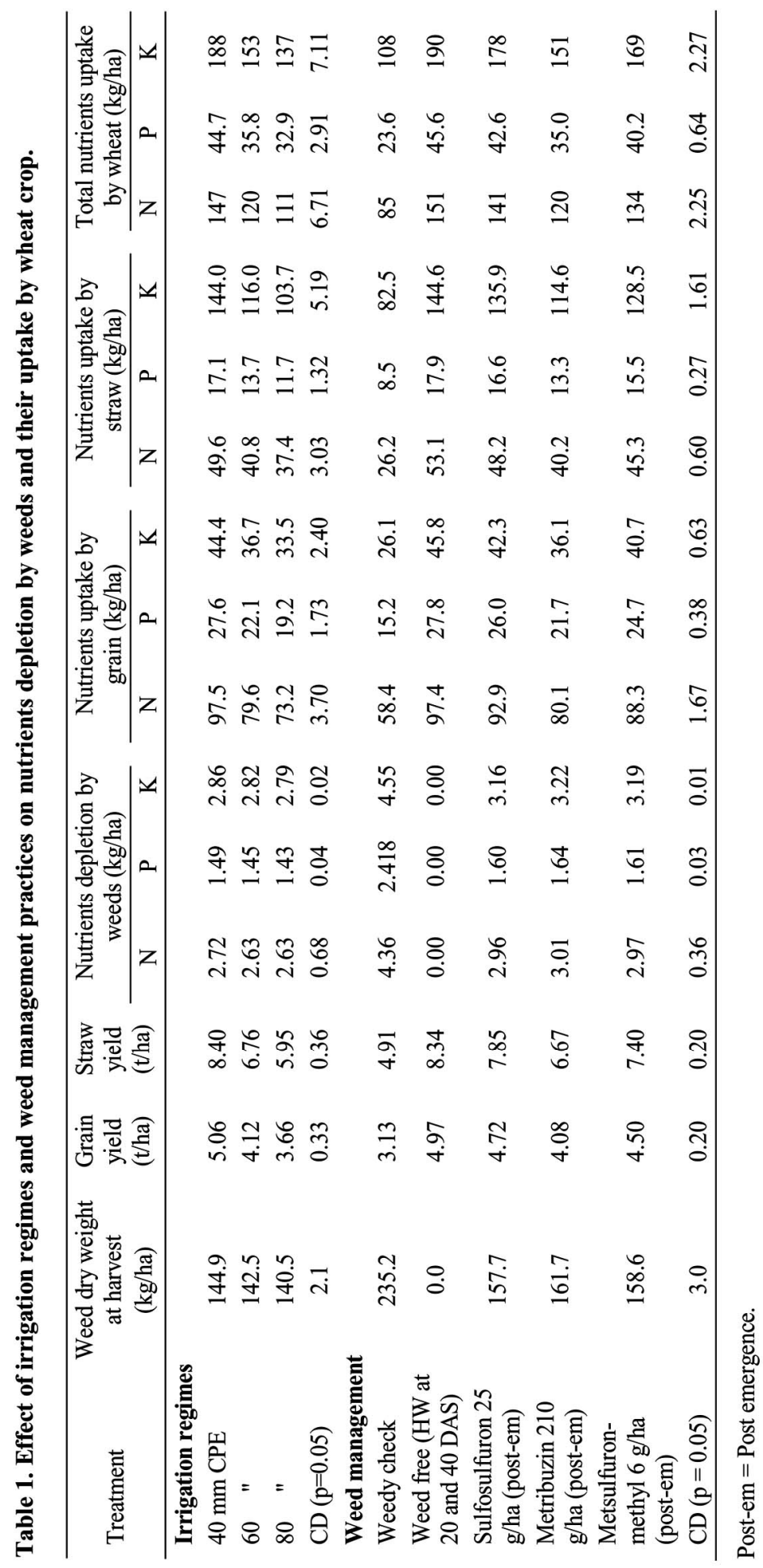




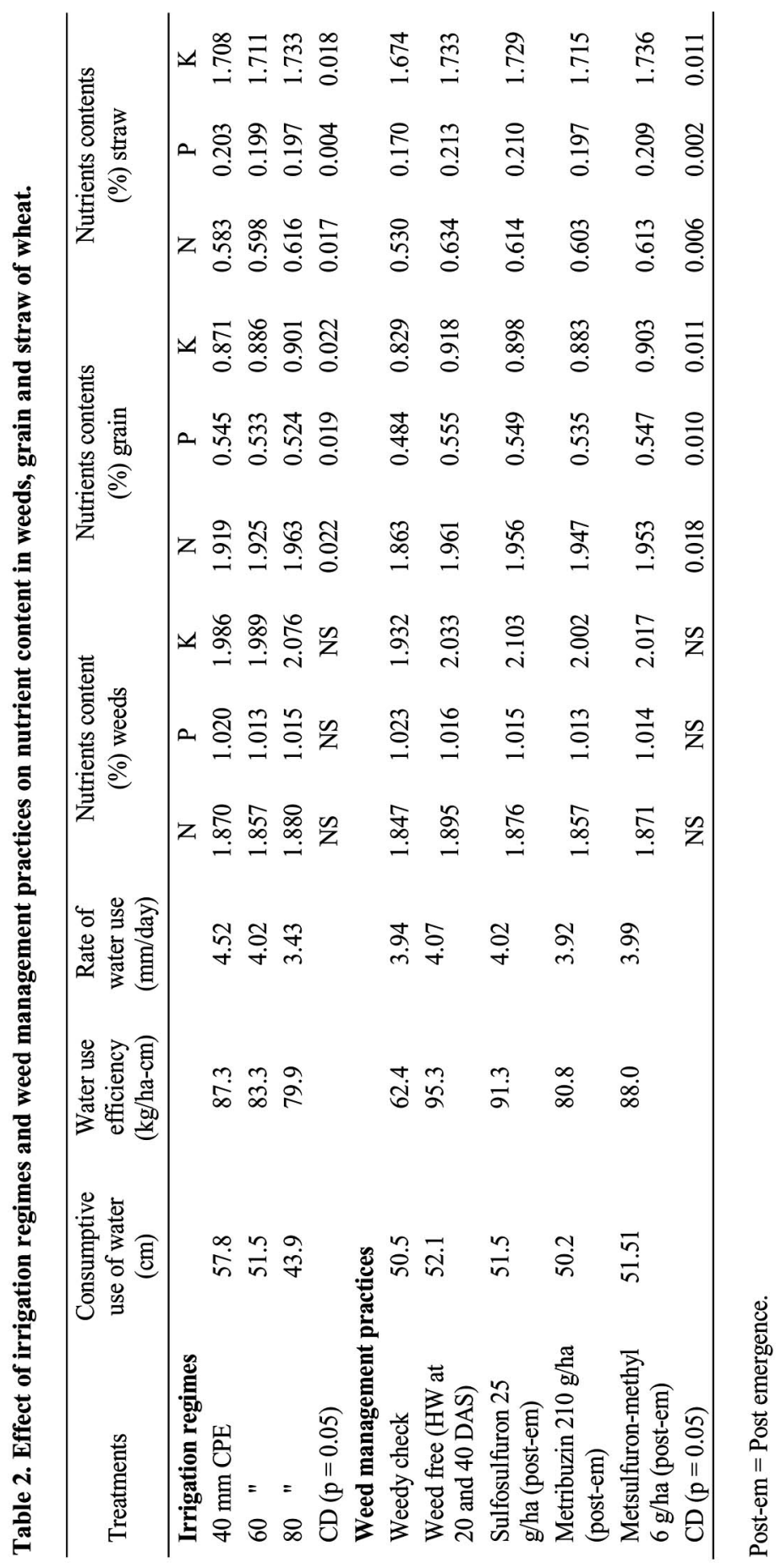


Irrigation at $40 \mathrm{~mm}$ CPE significantly influenced the $\mathrm{N}, \mathrm{P}$ and $\mathrm{K}$ uptake in grain and straw as well as total uptake of these nutrients by wheat (Table 2). It could be attributed to the better soil moisture conditions during plant growth which helped in better utilization of nutrient by the plant, thereby resulting in highest yield and nutrient uptake. The similar results were also reported by Pandey et al. (2006). Weed management practices significantly influenced the total N, P and K uptake by wheat. It was significantly highest with post-emergence application of sulfosulfuron over metribuzin and it was at par with metsulfuron-methyl. The increase in the uptake of nutrients by crop was due to the fact that lower density and dry weight of weeds under these treatments which helps in the better utilization of $\mathrm{N}, \mathrm{P}$ and $\mathrm{K}$, and other elements. The higher uptake of these nutrients was due to the higher yield, higher dry matter production and higher nutrient content in different parts of plants, which corroborated with the findings of Khokhar and Nepalia (2010).

\section{Acknowledgement}

The authors are thankful to the Head of the department of Agronomy BHU, Varanasi, for encouraging such research and providing necessary facilities for the successful completion of research work.

\section{References}

Bandyopadhyay KK, Singh R and Kundu DK 2010. Enhancing agricultural productivity through enhanced water use efficiency, J. Agric. Physics 10: 1-15.

Jain N, Mishra JS, Kewat ML and Jain V 2007. Effect of tillage and herbicides on grain yield and nutrient uptake by wheat and weeds. Ind. J. Agron. 52(2): 131-34.

Khokhar AK and Nepalia V 2010. Effect of herbicides and nutrient management on weed flora, nutrient uptake and yield of wheat nutrient uptake and yield if what. Ind. J. Weed Sci. 42(1/2): 14-18.

Mahbod M, Sepaskhah AR and Monfared M 2009. Development of an irrigation scheduling model for winter wheat based on soil water and precipitation. J. Sci. and Tech. Agric. and Natural Reso. 13(4-B): 1-12.

Masanta S and Mallik S 2009. Effect of mulch and irrigation on yield and water use efficiency of wheat unser Patloi Nala micrp-watershed in Pirulia district of West Bengal. J. Crop and Weed 5(2): 22-24.

Nadeem MA, Tanveer A, Ali A, Ayub M and Tahir M 2007. Effect of weed-control practice and irrigation levels on weeds and yield of wheat. Ind. J. Agron. 52(1): 60-63.

Nadeem MA, Tanveer A, Ali A, Ayub M and Tahir M 2010. Effect of weed control practices and irrigation levels on weeds and yield of wheat. Ind. J. Agron. 55: 60-63.

Pandey AK, Gopinath KA and Gupta HS 2006. Evaluation of sulfosulfuron and metribuzin for weed control in irrigated wheat. Ind. J. Agron. 51(2): 135-138.

Singh G, Singh OP, Singh S and Kanti P 2010. Weed management in late sown wheat after rice in rice-wheat system in rainfed lowland. Ind. J. Agron. 55(2): 83-88.

Singh RK, Verma SK, Sharma R and Singh SB 2009. Bio-efficacy and selectivity of sulfosulfuron and metribuzin before and after irrigation in wheat under zero-tillage system. Ind. J. Agri. Sci.79(9): 735-39.

Singh R and Singh B 2004. Effect of irrigation time and weed management practices on weeds and wheat yield. Ind. J. Weed Sci. 36(1\&2): 25-27.

Verma SK and Idnani LK 2012. Water use, nutrient content and their uptake as influenced by irrigation and nitrogen management in potato-maize cropping system. Ind. J. Agri. Sci. 82(12): 1032-38.

Verma SK, Singh SB, Sharma R, Rai OP and Singh G 2008. Effect of cultivars and herbicides on grain yield and nutrient uptake by wheat and weeds under zero-tillage system. Ind. J. Agri. Sci. 78(11): 884-87. 